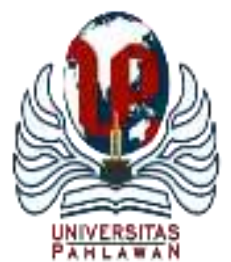

\title{
JURNALBASICEDU
}

Volume 6 Nomor 1 Tahun 2022 Halaman 633 - 645

Research \& Learningin Elementary Education

https://jbasic.org/index.php/basicedu

\section{Penerapan Model Simulasi Tentang Pembelajaran Mitigasi Bencana Alam Gempa Bumi Berbasis Video Animasi Untuk Meningkatkan Hasil Belajar Siswa}

\author{
Susi Mahmudah ${ }^{1 凶}$, Farah Fauzia $^{2}$ \\ Universitas Islam Negeri Sunan Kalijaga Yogyakarta, Indonesia ${ }^{1,2}$ \\ E-mail: susimahmudah3@gmail.com ${ }^{1}, \underline{\text { ffauzia25@gmail.com }}{ }^{2}$
}

\begin{abstract}
Abstrak
Proses belajar mengajar yang digunakan SDN 3 hanya menggunakan metode konvesional, sehingga anakanak kelihatannya kurang bersemangat dan kurang aktif dalam mengikuti pembelajaran. Oleh karena itu, peneliti mencoba memperkenalkan model simulasi karena model ini memberikan kesempatan kepada peserta didik untuk terlibat langsung menjadi orang lain sehingga akan memperoleh gagasan-gagasan baru dengan tujuan untuk meningkatkan hasil belajar siswa. Penelitian ini dilakukan di SDN 3 Semende Darat Ulu. Penelitian ini merupakan penelitian kuantitatif dengan menggunakan metode penelitian berbentuk eksperimen. Teknik pengumpulan data dalam penelitian ini menggunakan angket dan tes, teknik analisis data menggunakan analisi korelasi dengan rumus Product Of The Moment. Hasil dari penelitian ini menunjukkan bahwa penerapan model simulasi pada pembelajaran mitigasi bencana alam gempa bumi berbasis video animasi di SDN 3 Semende Darat Ulu dapat meningkatkan hasil belajar siswa.
\end{abstract}

Kata Kunci: Model simulasi, pembelajaran mitigasi bencana alam gempa bumi, video animasi, hasil belajar siswa, sekolah dasar

\begin{abstract}
The teaching and learning process used by SDN 3 only uses conventional methods, so the children seem less enthusiastic and less active in participating in learning. Therefore, researchers try to introduce a simulation model because this model provides opportunities for students to be directly involved in being other people so that they will get new ideas with the aim of improving student learning outcomes. This research was conducted at SDN 3 Semende Darat Ulu. This research is a quantitative research using experimental research methods. Data collection techniques in this study using questionnaires and tests, data analysis techniques using correlation analysis with the Product Of The Moment formula. The results of this study indicate that the application of simulation models in earthquake natural disaster mitigation learning based on animated videos at SDN 3 Semende Darat Ulu can improve student learning outcomes.
\end{abstract}

Keywords: Simulation model, earthquake natural disaster mitigation learning, animated video, student learning outcomes, elementary school

Copyright (c) 2022 Susi Mahmudah, Farah Fauzia

$\triangle$ Corresponding author :

Email : susimahmudah3@gmail.com

DOI $\quad$ : https://doi.org/10.31004/basicedu.v6i1.1974 


\section{PENDAHULUAN}

Peserta didik mempunyai berbagai macam potensi, karakter, dan kebutuhan dalam belajar, perbedaan yang dimiliki oleh peserta didik terletak pada pola pikir, daya imajinasi, pengandaian dan hasil karyanya, maka dari itu, pada proses pembelajaran guru diharuskan untuk memilih merancang suatu pembelajaran yang kreatif sebelum menyampaikan materi kepada peserta didik supaya dapat memberikan kesempatan dan kebebasan berkreasi secara berkesinambungan sehingga dapat mengoptimalkan kreativitas yang ada pada peserta didik. (Agustina, 2018, hal. 10) Dengan demikian, tujuan pembelajaran yang telah ditetapkan akan tercapai. Seorang guru tidak hanya mengajar atau menyempaikan materi saja akan tetapi mampu mendidik dan melatih peserta didik untuk mengembangkan keterampilan-keterampilan peserta didik dalam kehidupan sehari-hari, untuk dapat melaksanakan tugas di atas dengan penuh tanggung jawab, seorang guru harus memiliki berbagai kemampuan terutama dalam mengelola proses pembelajaran (Anwar, 2018, hal. 1).

Ketika akan melaksanakan proses pembelajaran seorang guru dituntut untuk dapat merencanakan dan melaksanakan suatu model pembelajaran agar tercipta proses interaksi dengan para siswa (Falahuddin \& Agustin, 2013). Dalam membuat perencanaan kegiatan belajar yang baik dan menarik para guru harus menysesuaikan dengan kebutuhan siswa supaya hasil belajar peserta didik sesuai dengan yang diharapkan. Maka harus menggunakan model pada saat mengajar karena kesuksesan belajar peserta didik juga sangat dipengaruhi oleh cara guru mengelola proses pembelajarannya. Guru harus kreatif dalam pemilihan model, strategi dan metode pembelajaran sebelum kegiatan pembelajaran dilaksanakan di kelas. Pemilihan model pembelajaran harus disesuaikan dengan karakteristik peserta didik, jumlah peserta didik dan karakteristik materi yang akan diajarkan.

Secara khusus 'model' diartikan sebagai kerangka konseptual yang digunakan sebagai pedoman dalam melakukan sesuatu kegiatan (Rahayu, 2017). Pembelajaran menurut Gagne dan Briggs adalah suatu sistem yang bertujuan untuk membantu proses belajar peserta didik, berisi serangkaian peristiwa yang dirancang dan disusun semenarik mungkin untuk mempengaruhi dan mendukung terjadinya proses belajar (Lefudin, 2014, hal. 13). Menurut Joice dan Weil model pembelajaran adalah pola atau rencana yang sudah dibuat sedemikian rupa oleh guru dan digunakan untuk menyusun kurikulum, mengatur materi pelajaran serta cara yang baik untuk menyampaikannya kepada peserta didik (Jumadi, 2017, hal. 3). Jadi, model pembelajaran dapat juga diartikan sebagai kerangka konseptual yang melukiskan prosedur yang sistematis dalam meningkatkankan pengalaman belajar peserta didik supaya tujuan pembelajaran yang telah ditetapkan dapat tercapai, dan berfungsi sebagai pedoman bagi para perancang pembelajaran atau para pengajar dalam merencanakan dan melaksanakan aktivitas belajar.

Dengan adanya model pembelajaran maka akan membuat proses pembelajaran lebih menarik. Semakin menarik tampilan media maka siswa semakin termotivasi untuk belajar sehingga mempengaruhi hasil belajar siswa (Kuswanto \& Radiansah, 2018). Adapun model pembelajaran yang bisa diterapkan dalam proses belajar mengajar supaya siswa bisa mengikuti pembelajaran dengan baik dan dalam penerapannya pun lebih efektif adalah dengan menggunakan model simulasi. Jenis model ini merupakan model yang diakui dengan baik untuk memahami dunia karena model ini memberikan kesempatan langsung kepada peserta didik untuk memahami dirinya sendiri maupun orang lain yang kemudian bisa diterapkan dalam kehidupannya sehari-hari baik itu di sekolah maupun di lingkungan sekitarnya.

Model simulasi pada dasarnya merupakan salah satu strategi pembelajaran yang bertujuan memberikan pengalaman belajar melalui penciptaan tiruan-tiruan yang mendekati suasana nyata (Oktapyanto, 2016). Model simulasi ini merupakan model pembelajaran yang dapat mengarahkan peserta didik sehingga tercipta suasana pembelajaran yang menyenangkan. Maka dari itu, saya ingin menerapkan model simulasi ini dalam pembelajaran mitigasi bencana alam gempa bumi. 
Indonesia secara geografis merupakan negara kepulauan yang terletak pada pertemuan empat lempeng tektonik yaitu lempeng Benua Asia, Benua Australia, lempeng Samudera Hindia dan Samudera Pasifik di bagian timur. Pertemuan lempeng inilah yang menyebabkan Indonesia memiliki banyak gunung api sehingga menjadi salah satu negara yang rawan dengan bencana (Nugroho, 2018). Jadi Indonesia ini merupakan negara yang memiliki tingkat kerawanan bencana alam yang tinggi, seperti letusan gunung api, gempa bumi, tsunami, banjir, tanah longsor, dan lain sebagainya.

Bencana merupakan suatu peristiwa atau rangkaian peristiwa yang mengancam dan mengganggu kehidupan dan penghidupan masyarakat yang disebabkan oleh beberapa faktor yakni faktor non alam maupun faktor manusia dan faktor alam itu sendiri (Ibrahim dkk., 2020). Bencana alam yang terjadi berdampak sangat kompleks bagi kehidupan manusia baik dari segi ekonomi, sosial dan kesehatan bahkan bencana alam ini mengakibatkan timbulnya korban jiwa, kerusakan lingkungan, kerugian harta benda, dan dampak psikologis baik itu dengan orang dewasa maupun anak-anak. Salah satu cara yang dapat digunakan buat penanggulangan bencana yang terjadi yaitu dengan mitigasi. Mitigasi merupakan upaya yang dilakukan untuk mengurangi bahaya supaya kerugian dapat diperkecil (Qurrotaini \& Nuryanto, 2020), mitigasi meliputi aktivitas dan tindakan-tindakan perlindungan yang dapat diawali dari kesiapsiagaan atau kewaspadaan sebelum bencana itu terjadi. Penanggulangan bencana bisa berupa penyelamatan, rehabilitasi dan relokasi.

Jadi kegiatan mitigasi ini bertujuan untuk meningkatkan kesiapan masyarakat dan pengurangan risiko bencana dalam jangka waktu yang panjang, mengurangi jumlah korban, dan diterapkan semaksimal mungkin untuk meminimalisir dampak negatif yang akan terjadi (Hayudityas, 2020). Maka dari itu saya akan menerapkan pembelajaran mitigasi bencana alam ini melalui model simulasi berbasis video animasi.

Video animasi merupakan film yang berasal dari pengolahan gambar tangan dengan audio yang sesuai sehingga menjadi gambar yang bergerak sesuai alur yang sudah ditentukan pada setiap hitungan waktu . Objek yang dimaksud bisa berupa gambar manusia, tulisan teks, gambar hewan, gambar tumbuhan, gedung, dll (Alimah, 2020). Jadi media video animasi ini adalah media audio visual yang mengkombinasikan gambar animasi yang telah dipilih kemudian dibuat bergerak sesuai dengan hitungan waktu dan ditambahkan audio yang sesuai. Video animasi ini memiliki banyak manfaatnya diantaranya: dapat digunakan oleh guru untuk mempersingkat waktu dalam menyampaikan materi kepada peserta didik, dapat meminimalisir kesalahan yang terjadi saat demonstrasi langsung di depan kelas, dapat menarik perhatian dan minat siswa lebih karena tampilan media yang dibuat menarik serta dapat dimanfaatkan oleh guru untuk menampilkan masalah yang autentik dalam meningkatkan keefektifan proses belajar mengajar. Penampilan video animasi dapat diatur oleh guru sesuai dengan keinginannya.

Video animasi memiliki empat fungsi sebagai media pembelajaran (Yudianto, 2017), yaitu sebagai atensi, afektif, kognitif dan kompensatoris. Dengan menggunakan model simulasi berbasis video animasi tersebut diharapkan hasil belajar peserta didik dapat meningkat. Menurut Nana Sudjana hasil belajar adalah suatu kompetensi atau kecakapan yang dapat dicapai oleh peserta didik setelah melalui kegiatan proses pembelajaran yang telah dirancang dan dilaksanakan oleh guru di suatu sekolah dan kelas tertentu (Rivai, Bandung, hal. 7). Menurut Oemar Hamalik hasil belajar merupakan perubahan tingkah laku pada diri seseorang setelah melaksanakan proses belajar tersebut. Kemudian menurut teori Taksonomi Bloom hasil belajar merupakan kemampuan yang dimiliki peserta didik setelah mengikuti proses pembelajaran yaitu kemampuan kognitif, afektif dan psikomotorik. Di mana ranah kognitif terdiri dari enam aspek yaitu ranah ingatan (C1), ranah pemahaman (C2), ranah penerapan (C3), ranah analisis (C4), Sintesis (C5) dan ranah penilaian (C6) (Nurrita, 2018, hal. 175). Dengan demikian, dapat disimpulkan bahwa hasil belajar merupakan hasil yang diberikan kepada peserta didik berupa penilaian atas kemampuan yang diperoleh baik berupa kognitif, afektif dan juga psikomotoriknya setelah mengikuti proses pembelajaran.

Di dalam penelitian sebelumnya yang dilakukan oleh (Sunami \& Aslam, 2021) dalam kajiannya dituliskan bahwa penggunaan video animasi sangat efektif digunakan dalam proses pembelajaran, apalagi saat 
ini sekolah diadakan secara online di mana sekolah-sekolah memanfaatkan teknologi informasi seperti handphone yang dilengkapi dengan aplikasi zoom meeting, WhatsApp, Youtube, Facebook dll. Aplikasi ini dapat membantu kita dalam merealisasikan video animasi yang telah disiapkan kepada peserta didik. Dan hasil penelitian menunjukkan bahwa video animasi dapat meningkatkan minat dan hasil belajar siswa sekolah dasar. Kemudian pada penelitian (Hapsari \& Zulherman, 2021) juga menghasilkan bahwa video animasi dalam hal ini berbentuk aplikasi canva dapat meningkatkan motivasi dan prestasi belajar siswa. Walaupun sudah ada beberapa yang meneliti tentang video animasi ini, saya tertarik melakukan penelitian di SDN 3 ini karena merupakan sekolah yang tinggal di desa dengan fasilitas sarana dan prasarana yang kurang maksimal, dengan harapan peserta didik dapat meengikuti proses pembelajaran dengan maksimal.

Berdasarkan hasil observasi awal yang peneliti lihat di SDN 3 Semende Darat Ulu, bahwa proses belajar mengajar yang digunakan sekolah tersebut hanya menggunakan metode konvesional, sehingga anakanak kelihatannya kurang bersemangat dan kurang aktif dalam mengikuti pembelajaran, mereka kelihatannya sibuk dengan kegiatan masing-masing seperti berbicara atau ngobrol dengan temannya dan sering minta izin ke kamar mandi pada saat proses pembelajaran berlangsung. Setelah melihat kondisi yang ada di sekolah tersebut peneliti mencoba mengenalkan model simulasi berbentuk video animasi kepada guru di sekolah tersebut.

Tujuan dari penelitian ini adalah untuk mengetahui pengaruh penerapan model simulasi berbasis video animasi untuk meningkatkan hasil belajar siswa kemudian untuk mengetahui perbedaan hasil belajar siswa sebelum diterapkan model simulasi berbasis video animasi dengan setelah diterapkannya model simulasi berbasis video animasi tersebut. Karena menurut peneliti model ini sangat membantu untuk membuat anakanak bersemangat dan lebih aktif dalam pembelajaran. Semakin menarik tampilan video animasi yang digunakan maka siswa akan semakin termotivasi untuk belajar sehingga hal tersebut akan mempengaruhi hasil belajar siswa. Jadi, dengan menggunakan media pembelajaran akan membuat proses pembelajaran lebih menarik dan dapat meningkatkan hasil belajar siswa. Hal ini sesuai dengan penelitian yang dilakukan oleh (Maretyaningrum, 2019) yang megatakan bahwa video animasi belum banyak diterapkan di sekolah dasar yang mengakibatkan hasil belajar peserta didik masih rendah, padahal siswa sekolah dasar harus belajar dengan konkrit atau yang lebih nyata. Maka dari itu video animasi ini sangat baik diterapkan supaya siswa lebih mudah memahami materi yang disampaikan apalagi dengan simulasi secara langsung peserta didik akan berkesan mengikuti proses pembelajaran.

Dari permasalahan di atas maka peneliti akan mengangkat judul yaitu: "Penerapan Model Simulasi tentang Pembelajaran Mitigasi Bencana Alam Gempa Bumi Berbasis Video Animasi untuk Meningkatkan Hasil Belajar Siswa. Penelitian ini yang menjadi pokok pembahasannya adalah tentang pengaruh penggunaan model simulasi dalam proses pembelajaran mitigasi bencana alam gempa bumi dengan berbasis video animasi untuk meningkatkan hasil belajar siswa, penelitian ini di lakukan di di SD Negeri 3 Semende Darat Ulu.

\section{METODE PENELITIAN}

Pada penulisan ini, peneliti menggunakan penelitian kuantitatif dengan tipe eksperimen. Dimana peneliti terjun langsung ke lapangan untuk menerapkan sebuah model simulai dengan bantuan video untuk pembelajaran mitigasi bencana alam gempa bumi. Sumber data yang diterapkan dalam penelitian ini berbentu kualitatif dengan memaparrkan sudah sejauh mana penggunaan model simulasi mengenai mitigasi bencana alam gempa bumi dengan bantuan video animasi agar hasil belajar siswa dapat ditingkatkan serta berupa data kuantitatif untk dapat menganalisis penggunaan model simulasi ini dengan bantuan video animasi yang dilakukan di SD Negeri 3 Semende Darat Ulu. Penelitian ini bertujuan untuk mengetahui sejauh mana pengaruh penggunaan model simulasi dengan bantuan video animasi agar hasil belajar siswa dapat 
ditingkatkan. Subjek dalam penelitian ini adalah kelas V dengan jumlah siswa 24 dengan penggunaan sampel Stratified Class sampling yaitu dengan sampel pada populasi berdasarkan kelas.

Dalam pengumpulan data menerapkan teknik angket dengan tujuan agar mengetahui hasil belajar siswa sebelum diterapkannya model simulasi dengan bantuan video animasi. Data pendukung lainnya adalah data observasi dengan cara mengamati dan mencatat segala proses kegiatan belajar yang dilakukan siswa dan guru SD Negeri 3 Semende Darat Ulu kelas V. Teknik analisis data yang diterapkan adalah analisis korelasi dengan rumus Product Of The Moment. Sistematika adalah sebgai berikut.

$$
r_{x y}=\frac{N \sum X Y\left(\sum X\right)\left(\sum Y\right)}{\sqrt{\left\{N \sum Y-\left(\sum X^{2}\right)\right\}\left\{N \sum Y^{2}-\left(\sum Y\right)^{2}\right\}}}
$$

\section{HASIL DAN PEMBAHASAN PENELITIAN}

Pendidikan pada dasarnya merupakan implementasi untuk mencerdaskan kehidupan bangsa, pendidikan sangat penting dalam kehidupan. Pendidikan adalah usaha sadar yang direncanakan untuk membuat suatu suasana dalam proses pembelajaran menjadi lebih menarik serta untuk mengembangkan potensi yang ada pada peserta didik (Radyuli dkk., 2019). Pembelajaran merupakan suatu kegiatan guru mengajar atau membimbing peserta didik menuju pendewasaan diri. Dalam hal ini, guru tidak hanya mengajar dalam bentuk menyampaikan materi saja melainkan bagimana menyampaikan materi dengan mengambil nilai-nilai dari materi yang disampaikan supaya ilmu pengetahuan yang didapatkan oleh peserta didik dapat bermanfaat untuk kehidupannya nanti (Kirom, 2017, hal. 70).

Supaya pembelajaran berjalan sesuai dengan tujuan yang telah ditetapkan, maka pembelajaran harus didukung dengan model pembelajaran yang tepat karena hal tersebut sangat menentukan hasil belajar peserta didik (Nande dkk., 2021). Pengunaan model pembelajaran bukanlah sesuatu yang baru, model pembelajaran merupakan suatu bentuk pembelajaran yang menggambarkan kegiatan proses belajar mengajar dari awal sampai akhir pembelajaran, yang dirancang oleh guru dengan memperhatikan karakteristik peserta didik, gaya belajar, materi pelajaran yang akan disampaikan, fasilitas yang tersedia sehingga dalam penyampaiannya bisa kondusif dan bisa dipahami oleh peserta didik. (Rahman, 2018, hal. 22)

Model pembelajaran sangat efektif digunakan sebagai pedoman perancangan dan pelaksanaan proses pembelajaran dan juga untuk meningkatkan kualitas pembelajaran, karena pada kegiatan pembelajaran siswa dituntut untuk berperan aktif dalam proses pembelajaran tersebut serta diharapkan mampu berpikir tingkat tinggi, menumbuhkan kekompakan dan rasa kerja sama yang baik antar kelompok dengan penuh tanggung jawab (Kusnadi, 2018, hal. 3). Selain itu, masih banyak lagi manfaat yang didapatkan dalam penggunaan model pembelajaran ini. (Octavia, 2020, hal. 15). Yaitu : Bagi guru dapat memudahkan dalam pelaksanaan tugas pembelajaran, dapat dijadikan sebagai alat untuk aktivitas peserta didik, memudahkan untuk melakukan analisis terhadap perilaku peserta didik secara personal maupun kelompok dalam waktu yang relatif singkat, dan memudahkan untuk menyusun bahan pertimbangan dasar dalam merencanakan Penelitian Tindakan Kelas (PTK) dalam rangka memberbaiki ataupun menyempurnakan kualitas pembelajaran di sekolah. adapun manfaat bagi siswa yaitu memberikan kesempatan yang luas untuk berperan aktif dalam kegiatan pembelajaran, memudahkan peserta didik dalam memahami materi pembelajaran yang disampaikan, mendorong semangat belajar dan ketertarikan mengikuti pembelajaran secara aktif dan penuh perhatian serta dapat melihat atau membaca pribadi di kelompoknya secara objektif.

Dalam penelitian ini peneliti memilih model simulasi, karena model simulasi diartikan sebagai sesuatu yang meniru atau sebagai kegiatan pembelajaran yang memberikan kesempatan kepada peserta didik untuk meniru suatu kegiatan dam proses pembelajaran, model simulasi ini bertujuan untuk memberikan kesempatan kepada peserta didik dalam berlatih menguasai keterampilan dan mengembangkan keterampilan yang ada 
pada diri peserta didik (Amos Neolaka, 2017, hal. 250). Jadi model simulasi ini sangat cocok diterapkan dalam proses pembelajaran untuk anak sekolah dasar karena dapat memberikan pengalaman langsung kepada peserta didik, apalagi untuk materi mitigasi bencana alam gempa bumi.

Sebagaimana yang kita ketahui bahwa Indonesia merupakan negara yang rawan akan bencana terutama gempa bumi, Kedatangan bencana secara tiba-tiba tidak dapat dihindari oleh manusia tetapi harus dihadapi dan mengantisipasi sebelum terjadinya bencana yaitu dengan belajar mitigasi bencana supaya dapat meningkatkan kewaspadaan ketika terjadi bencana dan dapat melakukan penanggulangan, makadari itu menanamkan kemampuan untuk menghadapi bencana dangat penting dilakukan sejak dini atau sedini mungkin (Setyowati, 2019, hal. 1).

Proses kegiatan mitigasi bencana yang dilakukan di sekolah terdiri dari beberapa kegiatan, diantara kegiatan tersebut ialah kegiatan edukasi tentang hal dasar mengenai bencana dan simulasi dalam menghadapinya, tanda kemunculan bencana, efek yang ditimbulkan dari bencana, dan juga usaha yang bisa di pakai dalam meminimalisir resiko dimulai sejak pra-bencana, saat terjadi bencana dan saat pasca bencana, usaha dalam meminimalisir resiko (Arifa, 2018, hal. 18). Kegiatan pembelajaran mitigasi bencana alam ini dilakukan kepada peserta didik atau anak-anak untuk memahamkan anak terkait informasi bencana, bagaimana menanggulanginya, memberikan bekal pengalaman dengan praktek simulasi bencana dan langkah seperti apa yang harus dilakukan jika terjadi bencana tersebut dengan tenang, tepat dan cepat (Setyanugrah \& Setyadi, 2017). Kegiatan pembelajaran mitigasi bencana banjir ini bertujuan untuk meningkatkan sikap kesiapsiagaan bencana banjir pada anak. Kesiapsiagaan adalah bentuk latihan berkoordinasi, berkomunikasi dan evakuasi dengan adanya keterlibatan dari semua pemangku kepentingan pemerintah dan masyarakat umum (Bencana, 2017, hal. 15).

Dalam proses pembelajaran di kelas, salah satu upaya yang bisa digunakan dalam pembelajaran mitigasi bencana alam gempa bumi di SD Negeri 3 Semende Darat Ulu yaitu dengan model simulasi berbasis video animasi. Video animasi merupakan suatu media pembelajaran yang dipresentasikan dalam bentuk gambar kombinasi dengan suara yang dibuat dengan menarik kemudian disimulasikan gambar dan suara tersebut yang menggambarkan peregrakan suatu objek (Sari, 2021). Penggunaan video animasi ini sangat membantu untuk meningkatkan daya tarik peserta didik dalam mengikuti proses pembelajaran. Adapun manfaat dari penggunaan video animasi ini (Afridzal, 2018), yaitu: mempermudah interaksi antara guru dan peserta didik, sehingga proses pembelajaran menjadi lebih efektif dan kondusif, guru tidak perlu menjelaskan materi secara berulang-ulang dan peserta didik mudah memahami materi yang disampaikan. Menurut Andi Pratowo manfaat video animasi (Prastowo, 2012, hal. 302) yaitu :

1. Memberikan pengalaman yang tak terduga kepada peserta didik,

2. Memperlihatkan secara nyata sesuatu yang pada awalnya tidak mungkin bisa dilihat,

3. Menganalisis perubahan dalam periode waktu tertentu,

4. Memberikan pengalaman kepada peserta didik untuk merasakan suatu keadaan tertentu,

5. Menampilkan presentasi studi kasus tentang kehidupan sebenarnya yang dapat memicu diskusi peserta didik.

Setiapa proses pembelajaran selalu menghasilkan hasil belajar. Hasil belajar merupakan salah satu acuan dalam proses pembelajaran. Kemampuan intelektual yang dimiliki oleh setiap peserta didik sangat mempengaruhi hasil belajarnya, kemudian dari pencapaian hasil belajar ini dapat dilihat dari perubahan perilaku peserta didik yang lebih baik dari segi kognitif, afektif maupun dari segi psikomotoriknya (Pebriani, 2017). Ada beberapa faktor yang mempengarhi hasil belajar yaitu faktor internal seperti kemampuan intelektual dan emosional. Kemudian ada juga faktor eksternal seperti tempat belajar, suasana belajar yang diterapkan oleh guu. Maka dari itu, keberhasilan belajar peserta didik sangat bergantung dengan cara guru mengelolah proses pembelajaran. 
Dari uraian di atas sudah dijelaskan bahwa penelitian ini dilakukan untuk mengetahui penerapan model simulasi tentang pembelajaran mitigasi bencana alam gempa bumi dengan bantuan video animasi agar hasil belajar siswa di SD Negeri 3 Semende Darat Ulu dapat ditingkatkan. Jadi, langkah pertama yang peneliti ambil untuk mengetahui apakah penerapan model simulasi tentang pembelajaran mitigasi bencana alam gempa bumi berbasis video animasi dapat meningkatkan hasil belajar siswa di SD Negeri 3 Semende Darat Ulu, peneliti terlebih dahulu mengajukan 10 item pertanyaan kepada 24 siswa sebelum penerapan model simulasi tersebut. Di mana setiap soal diberikan 4 pilihan untuk menjawabnya seperti a, b, c dan d. kemudian a diberikan skor 4, b diberikan skor 3, c diberikan skor 2 dan d diberikan skor 1. Kemudian data dari hasil belajar para siswa yang sudah diperoleh di analisis dengan penggunaan statistik.

$\begin{array}{llllll}25 & 27 & 30 & 31 & 25 & 24 \\ 26 & 24 & 20 & 29 & 27 & 25 \\ 22 & 21 & 26 & 23 & 21 & 20 \\ 25 & 28 & 20 & 25 & 22 & 21\end{array}$

Tabel 1 Distribusi Frekuensi Nilai Penerapan Model Simulasi

\begin{tabular}{cccccc}
\hline $\mathbf{X}$ & $\mathbf{F}$ & $\mathbf{F X}$ & $\mathbf{x}=\mathbf{X}-\mathbf{M x}$ & $\mathbf{x}^{\mathbf{2}}$ & $\mathbf{F x}^{\mathbf{2}}$ \\
\hline 31 & 1 & 31 & 6,54 & 42,77 & 42,77 \\
\hline 30 & 1 & 30 & 5,54 & 30,69 & 30,69 \\
\hline 29 & 1 & 29 & 4,54 & 20,61 & 20,61 \\
\hline 28 & 1 & 28 & 3,54 & 12,53 & 12,53 \\
\hline 27 & 2 & 54 & 2,54 & 6,45 & 12,9 \\
\hline 26 & 2 & 52 & 1,54 & 2,37 & 4,74 \\
\hline 25 & 5 & 125 & 0,54 & 0,29 & 1,45 \\
\hline 24 & 2 & 48 & $-0,46$ & 0,21 & 0,42 \\
\hline 23 & 1 & 23 & $-1,46$ & 2,13 & 2,13 \\
\hline 22 & 2 & 44 & $-2,46$ & 6,05 & 12,1 \\
\hline 21 & 3 & 63 & $-3,46$ & 11,97 & 35,91 \\
\hline 20 & 3 & 60 & $-4,46$ & 19,89 & 59,67 \\
\hline & $\mathrm{N}=24$ & $\sum F X=587$ & & & $\sum F X^{2}=235,92$ \\
\hline
\end{tabular}

Pada kolom ke empat langkah yang diambil untuk mencari Mx adalah:

$$
M_{x=\frac{\sum F X}{N}=\frac{587}{24}=24,46}
$$

Setelah kita mengetahui Mean, kemudian cara berikutnya kita mencari nilai standar deviasi (SD) yaitu dengan rumus sebagai berikut:

$$
\begin{aligned}
S D_{x} & =\frac{\sum F X^{2}}{N} \\
& =\frac{235,92}{24} \\
& =\sqrt{9,83} \\
& =3,13
\end{aligned}
$$

Setelah kita mengetahui hasil Mean dan Standar deviasi, lalu cara selanjutnya adalah kita akan menetapkan kategori TSR. Adapun kategori tersebut yaitu:

$$
\begin{aligned}
\text { Tinggi } & =\mathrm{Mx}+1 . \mathrm{SDx} \\
& =24,46+1 \cdot 3,13 \\
& =28 \\
\text { Sedang } & =\text { antara skor } 22 \text { sampai dengan } 27
\end{aligned}
$$




$$
\begin{aligned}
\text { Rendah } & =\mathrm{Mx}-1 . \mathrm{SDx} \\
& =24,46-1.3,13 \\
& =21
\end{aligned}
$$

Setelah memperoleh hasil di atas dapat disimpulkan bahwa:

1. Skor 28 ke atas merupakan nilai yang tinggi, hal ini menunjukkan bahwa hasil belajar siswa pada proses pembelajaran mitigasi bencana alam gempa bumi tergolong tinggi

2. Skor 22-27 merupakan nilai yang sedang, hal ini menunjukkan bahwa hasil belajar siswa pada proses pembelajaran mitigasi bencana alam gempa bumi tergolong sedang

3. Skor 21 ke bawah merupakan nilai yang rendah, hal ini menunjukkan bahwa hasil belajar siswa pada mata pembelajaran mitigasi bencana alam gempa bumi tergolong rendah. Berdasarkan jenis skor di atas yaitu tinggi, sedang, rendah (TSR) yang telah dijelaskan kemudian cara selanjutnya kita akan mengelompokkan hasil tersebut ke dalam rumus persentase berikut ini:

Tabel 2 Klasifikasi Jawaban Siswa tentang Pembelajaran Mitigasi Bencana Alam Gempa Bumi Sebelum Diterapkan Model Simulasi Berbasis Video Animasi.

\begin{tabular}{cccc}
\hline No & Kategori & Frekuensi & Persent \\
& & \multicolumn{2}{c}{ asi } \\
\hline 1 & Tinggi & 4 & 16,67 \\
\hline 2 & Sedang & 14 & 58,33 \\
\hline 3 & Rendah & 6 & 25 \\
\hline & Jumlah & $\mathbf{2 4}$ & $\mathbf{1 0 0}$ \\
\hline
\end{tabular}

Dari uraian tabel dua di atas dapat kita ketahui bahwa jawaban peserta didik tentang pembelajaran mitigasi bencana alam gempa bumi masuk ke dalam tiga kategori, ada yang masuk kategori tinggi, sedang dan rendah. Siswa kategori tinggi berjumlah 4 (16,67\%), sedang berjumlah $14(58,33 \%)$ siswa, dan kategori rendah berjumlah $6(25 \%)$ siswa.

Kalau di atas merupakan hasil belajar siswa sebelum diterapkan model simulasi berbasis video animasi, sekarang peneliti akan menyajikan hasil belajar siswa setelah menerapkan model simulasi berbasis video animasi. Jadi, peneliti menggunakan test untuk mengetahui hasil belajar siswa dengan menggunakan model simulasi dengan bantuan video animasi pada mitigasi bencana alam gempa bumi. Test dikerjakan dengan tertulis yang diberikan kepada setiap individu sebanyak 10 soal dengan skor setiap soal bernilai 10. Kemudian diperoleh skor mentah dari hasil test pembelajaran mitigasi bencana alam gempa bumi sebagai berikut:

$\begin{array}{llllll}95 & 95 & 90 & 85 & 90 & 75 \\ 95 & 80 & 95 & 90 & 75 & 95 \\ 80 & 95 & 70 & 70 & 85 & 65 \\ 90 & 85 & 95 & 90 & 80 & 95\end{array}$

Tabel 3 Distribusi Frekuensi Tes Hasil Belajar Siswa pada Pembelajaran Mitigasi Bencana Alam Gempa Bumi

\begin{tabular}{cccccc}
\hline $\mathbf{Y}$ & $\mathbf{F}$ & $\mathbf{F Y}$ & $\mathbf{y}=\mathbf{Y}-\mathbf{M y}$ & $\mathbf{y}^{\mathbf{2}}$ & $\mathbf{F y}^{\mathbf{2}}$ \\
\hline 95 & 8 & 760 & 9,17 & 84,09 & 672,72 \\
\hline 90 & 5 & 450 & 4,17 & 17,39 & 86,95 \\
\hline 85 & 3 & 255 & $-0,83$ & 0,69 & 2,07 \\
\hline 80 & 3 & 240 & $-5,83$ & 33,99 & 101,97 \\
\hline
\end{tabular}


Video Animasi Untuk Meningkatkan Hasil Belajar Siswa - Susi Mahmudah, Farah Fauzia

DOI: https://doi.org/10.31004/basicedu.v6i1.1974

\begin{tabular}{cccccc}
\hline 75 & 2 & 150 & $-10,83$ & 117,29 & 234,58 \\
\hline 70 & 2 & 140 & $-15,83$ & 250,59 & 501,18 \\
\hline 65 & 1 & 65 & $-20,83$ & 433,89 & 433,89 \\
\hline & $\mathrm{N}=24$ & $\sum F Y=2.060$ & & & $\sum F Y^{2}=2.033,36$ \\
\hline
\end{tabular}

Pada kolom ke-3 langkah yang diambil dalam mencari Mx adalah:

$$
M_{y=\frac{\sum F Y}{N}=\frac{2.060}{24}=85,83}
$$

Setelah kita mengetahui Mean, kemudian cara berikutnya kita harus mencari nilai standar deviasi (SD) rumusnya yaitu:

$$
\begin{aligned}
S D_{y} & =\frac{\sum F Y^{2}}{N} \\
& =\frac{2.033,36}{24} \\
& =\sqrt{84,72} \\
& =9,2
\end{aligned}
$$

Setelah kita mengetahui hasil Mean dan Standar deviasi, maka langkah selanjutnya adalah kita akan menetapkan kategori TSR. Adapun kategori tersebut yaitu:

$$
\begin{aligned}
\text { Tinggi } & =\text { My }+1 . \text { SDy } \\
& =85,83+1.9,2 \\
& =95 \\
\text { Sedang } & =\text { antara skor } 78 \text { sampai dengan } 94 \\
\text { Rendah } & =\text { My }-1 . \text { SDy } \\
& =85,83-1.9,2 \\
& =77
\end{aligned}
$$

Dari uraian di atas dapat disimpulkan bahwa:

1. Skor 95 ke atas merupakan nilai yang tinggi, hal ini menunjukkan bahwa hasil belajar siswa pada proses pembelajaran mitigasi bencana alam gempa bumi tergolong tinggi

2. Skor 78-94 merupakan nilai yang sedang, hal ini menunjukkan bahwa hasil belajar siswa pada proses pembelajaran mitigasi bencana alam gempa bumi tergolong sedang

3. Skor 77 ke bawah merupakan nilai yang rendah, hal ini menunjukkan bahwa hasil belajar siswa pada mata pembelajaran mitigasi bencana alam gempa bumi tergolong rendah. Berdasarkan kategori skor tinggi, sedang, rendah (TSR) yang telah dijelaskan di atas maka langkah selanjutnya kita akan memasukkan hasil tersebut ke dalam rumus persentase berikut ini:

Tabel 4 Klasifikasi Jawaban Siswa tentang Pembelajaran Mitigasi Bencana Alam Gempa Bumi Setelah Diterapkan Model Simulasi Berbasis Video Animasi.

\begin{tabular}{cccc}
\hline No & Kategori & Frekuensi & Persentasi \\
\hline 1 & Tinggi & 8 & 33,34 \\
\hline 2 & Sedang & 11 & 45,83 \\
\hline 3 & Rendah & 5 & 20,83 \\
\hline & Jumlah & $\mathbf{2 4}$ & $\mathbf{1 0 0}$ \\
\hline
\end{tabular}

Dari tabel 4 di atas bisa kita lihat bahwa kategori jawaban siswa tentang pembelajaran mitigasi bencana alam gempa bumi setelah diterapkannya model simulasi berbasis video animasi terdapat peningkatan dimana jumlah siswa dengan kategori tinggi sebanyak 8 siswa dengan presentase $(33,34 \%)$, dan 11 siswa dengan presentase $(45,83 \%)$, dan 5 siswa dengan presentase $(20,83 \%)$.

Di atas telah kita dapatkan hasil belajar siswa sebelum menerapkan model simulasi dan hasil belajar siswa setelah menerapkan model simulasi. Jadi, Untuk mengetahui apakah ada pengaruh antara penerapan 
model simulasi terhadap hasil belajar peserta didik, maka dilakukan hipotetis atara variabel $\mathrm{X}$ dan variabel Y yaitu sebagai berikut:

\begin{tabular}{llllll}
\multicolumn{6}{l}{ Variabel X (Penerapan Model Simulasi) } \\
25 & 27 & 30 & 31 & 25 & 24 \\
26 & 24 & 20 & 29 & 27 & 25 \\
22 & 21 & 26 & 23 & 21 & 20 \\
25 & 28 & 20 & 25 & 22 & 21
\end{tabular}

Variabel Y (Hasil Belajar Siswa Kelas V)

$\begin{array}{llllll}95 & 95 & 90 & 85 & 90 & 75 \\ 95 & 80 & 95 & 90 & 75 & 95 \\ 80 & 95 & 70 & 70 & 85 & 65 \\ 90 & 85 & 95 & 90 & 80 & 95\end{array}$

Tabel 5 Perhitungan Mencari Pengaruh Antara Variabel X (Penerapan Model Simulasi) dan Y (Hasil Belajar Siswa)

\begin{tabular}{lccccc}
\hline \multicolumn{1}{c}{ Nama } & $\mathbf{X}$ & $\mathbf{Y}$ & $\mathbf{X Y}$ & $\mathbf{X}^{\mathbf{2}}$ & $\mathbf{Y}^{\mathbf{2}}$ \\
\hline Alif & 25 & 95 & 2375 & 625 & 9025 \\
\hline Ana & 26 & 95 & 2470 & 676 & 9025 \\
\hline Andri & 22 & 80 & 1760 & 484 & 6400 \\
\hline Bayu & 25 & 90 & 2250 & 625 & 8100 \\
\hline Danu & 27 & 95 & 2565 & 729 & 9025 \\
\hline Dodi & 24 & 80 & 1920 & 576 & 6400 \\
\hline Eva & 21 & 95 & 1995 & 441 & 9025 \\
\hline Farhan & 28 & 85 & 2380 & 784 & 7225 \\
\hline Farhanah & 30 & 90 & 2700 & 900 & 8100 \\
\hline Hafiza & 20 & 95 & 1900 & 400 & 9025 \\
\hline Husni & 26 & 70 & 1820 & 676 & 4900 \\
\hline Ilmah & 20 & 95 & 1900 & 400 & 9025 \\
\hline Iqbal & 31 & 85 & 2635 & 961 & 7225 \\
\hline Luvita & 29 & 90 & 2610 & 841 & 8100 \\
\hline Maliana & 23 & 70 & 1610 & 529 & 4900 \\
\hline Okta & 25 & 90 & 2250 & 625 & 8100 \\
\hline Puza & 25 & 90 & 2250 & 625 & 8100 \\
\hline Rafli & 27 & 75 & 2025 & 729 & 5625 \\
\hline Risna & 21 & 85 & 1785 & 441 & 7225 \\
\hline Rizal & 22 & 80 & 1760 & 484 & 6400 \\
\hline Sari & 24 & 75 & 1800 & 576 & 5625 \\
\hline Silva & 25 & 95 & 2375 & 625 & 9025 \\
\hline Sinta & 20 & 65 & 1300 & 400 & 4225 \\
\hline Wilia & 21 & 95 & 1995 & 441 & 9025 \\
\hline & $\sum 587$ & $\sum Y=2060$ & $\sum X Y=50430$ & $\sum X^{2}=14593$ & $\sum Y^{2}=178850$ \\
\hline & & & & &
\end{tabular}




$$
\begin{aligned}
r_{x y}=\frac{N \sum X Y\left(\sum X\right)\left(\sum Y\right)}{\sqrt{\left\{N \sum Y-\left(\sum X^{2}\right)\right\}\left\{N \sum Y^{2}-\left(\sum Y\right)^{2}\right\}}} \\
=\frac{24 x 50430-(587)(2060)}{\sqrt{\left\{24 x 14593-(587)^{2}\right\}\left\{24 x 178850-(2060)^{2}\right\}}} \\
=\frac{1210320-1209220}{\sqrt{\{350232-344569\}\{4292400-4243600\}}} \\
=\frac{11000}{\sqrt{\{5663\}\{48800\}}} \\
=\frac{1100}{\sqrt{276354400}} \\
=\frac{1100}{1662} \\
=0,661
\end{aligned}
$$

Langkah selanjutnya adalah mencari nilai $\mathrm{df}$ dengan memakai rumus $\mathrm{df}=\mathrm{N}-\mathrm{nr}=24-2=22$. Dengan penggunaan tabel " $r$ " maka dapat diketahui nilai dari pada df adalah 22, dengan nilai 0.661 dan taraf signifikansi sebesar 5\% yang didapat dari rt sebesar 0,404. Karena taraf dari signifikansinya 5\% maka dikatakan lebih besar dari $r$ tabel yaitu $(0,661>0,404)$. Maka hipotesis yang dihasilkan adalah nihil ditolak, tetatp pada hipotesis alternatif diterima. Pada taraf signifikansi yang lain adalah $1 \%$ maka rt sebesar 0,515. Karena taraf signifikansi sebesar $1 \%$ yang bisa dikatakan lebih besar dari $r$ tabel maka hipotesis nihil ditolak tetapi hipotesis alternatifnya diterima. Taraf signifikansi $5 \%$ dan $1 \%$ pada variabel $\mathrm{X}$ dan $\mathrm{Y}$ memiliki pengaruh yang dikatakan signifikan, penelitian ini dapat memperkuat apa yang sudah diteliti sebelumnya, diantaranya:

1. Penelitian (Afridzal, 2018) yang berjudul Perbedaan Hasil Belajar Menggunakan Media Gambar dan Video Animasi Pada Materi Karangan Deskripsi di Kelas III SD Negeri 28 Banda Aceh. Hasil penelitiannya menunjukkan bahwa ada perbedaan hasil belajar menggunakan media gambar dan video animasi pada materi karangan. Persamaan dengan penelitian ini ialah sama-sama membahas video animasi dan hasil belajar, perbedaannya penelitian sekarang menggunakan video animasi dengan disimulasikan pada pembelajaran mitigasi bencana alam gempa bumi.

2. Penelitian (Falahuddin \& Agustin, 2013) Dengan judul penelitiannya, Penerapan Metode Simulasi tentang Perkembangbiakan Vegetatif Buatan dalam Meningkatkan Hasil Belajar Siswa. Hasil penelitiannya menunjukkan bahwa ada pengaruh yang signifikan antara penerapan metode simulasi dengan hasil belajar. Persamaan dengan penelitian ini ialah sama-sama membahas simulasi dan hasil belajar, perbedaannya peneliti sekarang menerapkan metode simulasi berbasis video animasi.

3. Penelitian (Pebriani, 2017) dengan judul penelitiannya, Pengaruh Media Video Terhadap Motivasi Belajar dan Hasil Belajar Kognitif Pembelajaran IPA Kelas V Sekolah Dasar. Hasil penelitiannya menunjukkan bahwa ada pengaruh yang positif pada pembelajaran IPA dengan menggunak video animasi. Persamaan dengan penelitian ini ialah sama-sama membahas media video dan hasil belajar, perbedaannya peneliti sekarang media video disimulasikan kemudian tidak ada bahasan tentang motivasi

4. Penelitian (Sari, 2021) dengan judul penelitiannya, Peningkatakan Hasil Belajar Matematika Siswa Kelas VI Melalui Penerapan Media Video Animasi. Hasil penelitiannya menunjukkan bahwa penggunaan media video animasi dapat meingkatkan hasil belajar siswa. Persamaan dengan penelitian 
ini ialah sama-sama membahas video animasi dan hasil belajar. Perbedaannya peneliti sekarang video disimulasikan kemudian materinya ada Matematika ada IPS.

5. Penelitian (Nurrita, 2018) dengan judul penelitiannya, Pengembangan Media Pembelajaran untuk Meningkatkan Hasil Belajar Siswa. Hasil penelitiannya menunjukkan bahwa ada peningkatan hasil belajar dengan media pembelajaran. Persamaan dengan penelitian ini ialah sama-sama membahas media pembelajaran dan hasil belajar, perbedaannya terletak pada maeti bahasan dan media yang digunakan.

Jadi, dengan menggunakan model pembelajaran dapat membuat peserta didik tertarik mengikuti proses pembelajaran dengan baik, terutama model simulasi berbasis video animasi karena berdasarkan penelitian yang sudah dilakukan di atas dapat meningkatkan hasil belajar peserta didik.

\section{KESIMPULAN}

Berdasarkan hasil penelitian dan pembahasan di atas yaitu tentang penerapan model simulasi tentang pembelajaran mitigasi bencana alam gempa bumi berbasis video animasi untuk meningkatkan hasil belajar siswa di SD Negeri 3 Semende Darat Ulu, setelah data didapatkan kemudian dianalisis dengan taraf signifikansi $5 \%$ dan $1 \%$ diperoleh bahwa rt lebih kecil dari ro $0,404<0,661>0,515$ dapat ditarik kesimpulan bahwa ada pengaruh yang signifikan antara penerapan model simulasi berbasis video animasi dalam meningkatkan hasil belajar siswa di SD Negeri 3 Semende Darat Ulu. Semoga penelitian tentang model simulasi ini dapat menambah khazanah untuk semua orang khususnya guru dan dapat diterapkan dalam proses pembelajaran karena model simulasi ini memberikan pengalaman langsung kepada peserta didik sehingga peserta didik akan menjadi lebih aktif dalam mengikuti proses pembelajaran dan dapat meningkatkan hasil belajar peserta didik. Demikian penelitian ini dapat dilakukan insya Allah bermanfaat dan dapat dijadikan bahan acuan untuk penelitian selanjutnya.

\section{UCAPAN TERIMA KASIH}

Terima kasih kepada Bapak Dr. Andi Prastowo selaku Dosen Pengampu Mata Kuliah Pembelajaran Berbasis Teknologi Informasi dan Komunikasi yang selalu membimbing peneliti sehingga bisa melalukan penelitian tentang model simulasi ini. Kemudian terima kasih juga kepada SD Negeri 3 Semende Darat Ulu yang telah mengizinkan peneliti untuk melakukan penelitian serta dewan guru khususnya wali kelas $\mathrm{V}$ dan siswa kelas V SD Negeri 3 Semende Darat Ulu atas kerjasamanya sehingga penelitian ini dapat berjalan dengan baik.

\section{DAFTAR PUSTAKA}

Afridzal, A. (2018). Perbedaan Hasil Belajar Menggunakan Media Gambar Dan Video Animasi Pada Materi Karangan Deskripsi Di Kelas Iii Sd Negeri 28 Banda Aceh. Jurnal Tunas Bangsa, 5(2), 231-247.

Alimah, N. (2020). Penerapan Media Pembelajaran Video Animasi Untuk Meningkatkan Keterampilan Memperkenalkan Anggota Keluarga Dalam Pembelajaran Bahasa Indonesia Pada Peserta Didik Kelas I Sdi Alfattah Kecamatan Banjarsari Kota Surakarta Tahun Pelajaran 2020/2021. Jp3 (Jurnal Pendidikan Dan Profesi Pendidik), 6(1). Https://Doi.Org/10.26877/Jp3.V6i1.7299

Falahuddin, I., \& Agustin, M. (2013). Penerapan Metode Simulasi Tentang Perkembangbiakan Vegetatif Buatan Dalam Meningkatkan Hasil Belajar Siswa Pada Mata Pelajaran Ipa Di Madrasah Ibtidaiyah Pangeran Aji Kabupaten Oku Timur. Ta'dib: Jurnal Pendidikan Islam, 18(01), 1-15. Https://Doi.Org/10.19109/Td.V18i01.36 
Hapsari, G. P. P., \& Zulherman, Z. (2021). Pengembangan Media Video Animasi Berbasis Aplikasi Canva Untuk Meningkatkan Motivasi Dan Prestasi Belajar Siswa. Jurnal Basicedu, 5(4), 2384-2394. Https://Doi.Org/10.31004/Basicedu.V5i4.1237

Hayudityas, B. (2020). Pentingnya Penerapan Pendidikan Mitigasi Bencana Di Sekolah Untuk Mengetahui Kesiapsiagaan Peserta Didik. Jurnal Edukasi Nonformal, 1(1), 94-102.

Ibrahim, K., Emaliyawati, E., \& Yani, D. I. (2020). Pelatihan Dan Simulasi Penanggulangan Bencana Bagi Masyarakat. 3(1), 12.

Kuswanto, J., \& Radiansah, F. (2018). Media Pembelajaran Berbasis Android Pada Mata Pelajaran Sistem Operasi Jaringan Kelas Xi. Jurnal Media Infotama, 14(1). Https://Doi.Org/10.37676/Jmi.V14i1.467

Maretyaningrum, A. (2019). Pengembangan Media Pembelajaran Video Animasi Tari Kreasi Daerah Untuk Meningkatkan Hasil Belajar Siswa Kelas Iv Sdn Tambakaji 02 Semarang.

Nande, M., Banda, Y. M., \& Mbaru, Y. (2021). Penerapan Hasil Belajar Mata Pelajaran Ekonomi Dengan Model Pembelajaran Cooperative Script. Edukatif: Jurnal Ilmu Pendidikan, 3(2), 396-403. Https://Doi.Org/10.31004/Edukatif.V3i2.319

Nugroho, A. (2018). Pengembangan Model Pembelajaran Mitigasi Bencana Gunung Meletus Di Sekolah Dasar Lereng Gunung Slamet. Jurnal Pengabdian Masyarakat Multidisiplin, 1(2), 131-137. Https://Doi.Org/10.36341/Jpm.V1i2.413

Nurrita, T. (2018). Pengembangan Media Pembelajaran Untuk Meningkatkan Hasil Belajar Siswa. Misykat: Jurnal Ilmu-Ilmu Al-Quran, Hadist, Syari'ah Dan Tarbiyah, 3(1), 171-210. Https://Doi.Org/10.33511/Misykat.V3n1.171

Oktapyanto, R. R. Y. (2016). Penerapan Model Pembelajaran Simulasi Untuk Meningkatkan Keterampilan Sosial Anak Sekolah Dasar. 2(1), 13.

Pebriani, C. (2017). Pengaruh Penggunaan Media Video Terhadap Motivasi Dan Hasil Belajar Kognitif Pembelajaran Ipa Kelas V. Jurnal Prima Edukasia, 5(1), 11-21. Https://Doi.Org/10.21831/Jpe.V5i1.8461

Qurrotaini, L., \& Nuryanto, N. (2020). Implementasi Pendidikan Mitigasi Bencana Alam Gempa Bumi Dalam Pembelajaran Ips Sd. Trapsila: Jurnal Pendidikan Dasar, 2(01), 37 Https://Doi.Org/10.30742/Tpd.V2i01.885

Radyuli, P., Sefriani, R. S., \& Qomariah, N. (2019). Pembelajaran Inquiry Menggunakan Google Form Terhadap Hasil Belajar Simulasi Dan Komunikasi Digital. Edukatif: Jurnal Ilmu Pendidikan, 1(2), 5663. Https://Doi.Org/10.31004/Edukatif.V1i2.6

Rahayu, S. (2017). Model Simulasi Dalam Mata Kuliah Strategi Pembelajaran Fisika. Jurnal Pendidikan Fisika Dan Teknologi, 1(2), 118. Https://Doi.Org/10.29303/Jpft.V1i2.246

Sari, D. P. (2021). Peningkatan Hasil Belajar Matematika Siswa Kelas Vi Melalui Penerapan Media Video Animasi. Science: Jurnal Inovasi Pendidikan Matematika Dan Ipa, I(1), 39-45. Https://Doi.Org/10.51878/Science.V1i1.191

Setyanugrah, F., \& Setyadi, D. I. (2017). Perancangan Board Game Sebagai Media Pembelajaran Mitigasi Kebakaran Untuk Anak Sekolah Dasar Usia 8-12 Tahun Di Surabaya. Jurnal Sains Dan Seni Its, 6(1), F62-F68. Https://Doi.Org/10.12962/J23373520.V6i1.22949

Sunami, M. A., \& Aslam, A. (2021). Pengaruh Penggunaan Media Pembelajaran Video Animasi Berbasis Zoom Meeting Terhadap Minat Dan Hasil Belajar Ipa Siswa Sekolah Dasar. Jurnal Basicedu, 5(4), 1940-1945. Https://Doi.Org/10.31004/Basicedu.V5i4.1129

Yudianto, A. (2017). Penerapan Video Sebagai Media Pembelajaran. 234-237. Http://Eprints.Ummi.Ac.Id/354/ 